\title{
KNOWLEDGE-WORKER PRODUCTIVITY IN DEFENCE INDUSTRY: THE ROLE OF KNOWLEDGE MANAGEMENT THROUGH EMPLOYEES' ADAPTABILITY AND JOB SATISFACTION
}

\author{
Nawangsari Wardhani \\ Faculty of Economics and Business, Brawijaya University \\ Email : nawangsari.wardhani@gmail.com (corresponding author) \\ Noermijati Noermijati \\ Faculty of Economics and Business, Brawijaya University \\ Email :nurmi@ub.ac.id \\ Sunaryo Sunaryo \\ Faculty of Economics and Business, Brawijaya University \\ Email : sunaryo@ub.ac.id
}

Received: November 2021; Accepted: December 2021; Available online: January 2022

\begin{abstract}
This research aims to reveal the effect of knowledge management on knowledge-worker productivity which is also mediated by employees' adaptability and job satisfaction. The research was conducted at PT. Pindad (Persero) Malang as a manufacturing industry company based on specific knowledge. The research population is 389 employees who work in departments that are closely related to ammunition products knowledge. Furthermore, 203 employees became the research sample which was taken proportionally and randomly using the proportional random sampling technique. Structural equation modeling (SEM) with partial least squares (PLS) approach was applied as a data analysis method. The results of the study reveal that knowledge management has no significant effect on knowledge-worker productivity, but knowledge management has a significant effect on adaptability, and adaptability has a significant effect on knowledge-worker productivity. Knowledge management also has a significant effect on job satisfaction, and job satisfaction also has a significant effect on knowledge-worker productivity. Thus, adaptability and job satisfaction have a full mediating role on the effect of knowledge management on knowledge-worker productivity. This research contributes to the defense industry to immediately increase knowledge-worker productivity by implementing knowledge management practices without ignoring the importance of employees' adaptability and job satisfaction.
\end{abstract}

Keywords: knowledge-worker productivity, knowledge management, adaptability, job satisfaction.

\begin{abstract}
Abstrak
Penelitian ini ditujukan untuk mengungkap pengaruh manajemen pengetahuan terhadap knowledge-worker productivity yang sekaligus dimediasi oleh kemampuan adaptasi dan kepuasan kerja karyawan. Penelitian dilaksanakan di PT. Pindad (Persero) Malang sebagai perusahaan industri manufaktur berbasis pengetahuan spesifik. Populasi penelitian adalah 389 pegawai yang bekerja di departemen yang berkaitan erat dengan pengetahuan produk amunisi. Selanjutnya 203 karyawan menjadi sampel penelitian yang diambil secara proporsional dan acak dengan teknik proportional random sampling. Structural equation modeling (SEM) dengan pendekatan partial least square (PLS) diterapkan sebagai metode analisis data. Hasil penelitian mengungkapkan bahwa manajemen pengetahuan tidak berpengaruh signifikan terhadap knowledge-worker productivity, tetapi manajemen pengetahuan berpengaruh signifikan terhadap kemampuan adaptasi, dan kemampuan
\end{abstract}


adaptasi berpengaruh signifikan terhadap knowledge-worker productivity. Manajemen pengetahuan juga memiliki pengaruh signifikan terhadap kepuasan kerja, dan kepuasan kerja juga memiliki pengaruh signifikan terhadap knowledge-worker productivity. Dengan demikian, kemampuan adaptasi dan kepuasan kerja memiliki peran mediasi penuh pada pengaruh manajemen pengetahuan terhadap knowledge-worker productivity. Penelitian ini memberikan kontribusi pada industri pertahanan untuk segera meningkatkan knowledgeworker productivity dengan menerapkan praktik manajemen pengetahuan tanpa mengabaikan pentingnya kemampuan adaptasi dan kepuasan kerja karyawan.

Kata kunci: knowledge-worker productivity, manajemen pengetahuan, kemampuan adaptasi, kepuasan kerja.

How to Cite: Wardhani, N., Noermijati, N., \& Sunaryo, S. (2022). Knowledge-Worker Productivity in Defense Industry: The Role of Knowledge Management through Employees' Adaptability and Job Satisfaction. Media Ekonomi dan Manajemen, 37(1), 140-160. doi: http://dx.doi.org/10.24856/mem.v37i1.2597.

\section{INTRODUCTION}

Knowledge workers, as well as their productivity, are an important concern for industry in developing countries in the twenty-first century (Drucker, 1999). This productivity is known as knowledgeworker productivity. This condition can be defined as a level of productivity achieved by workers having knowledge. This productivity is now mostly determined by knowledge, or, to put it another way, employee knowledge can increase their work productivity. Quantity, quality, work autonomy, timeliness, efficiency, effectiveness, innovation or creativity, cost or profitability, customer satisfaction, job responsibilities, and employee attendance levels are some of the conditions that can reflect knowledge-worker productivity (Ramirez and Nembhard, 2004).

One of the State-Owned Enterprises in Indonesia that is in the field of defence industry that emphasize knowledge-worker productivity is PT. Pindad (Persero). PT. Pindad (Persero) produces military and commercial products, faces very complex manufacturing dynamics because it has a high demand for customization from customers. PT. Pindad (Persero) has the obligation to produce 154 variations of defence equipment products, all of which contain specific knowledge (PT. Pindad (Persero), 2021). Specific knowledge is specialized knowledge that requires an indepth understanding of a particular field and is very limited and expensive to transfer because it requires an understanding of the dynamics of the industrial context and technology (BecerraFernandez and Sabherwal, 2015). The large variety of products causes several obstacles in completing production. The average production realization in 2019 is around $45 \%$, while the average production cost in 2019 has increased by around 14\% from the production cost in 2018 (PT. Pindad (Persero), 2019). This condition is an obstacle to achieving the effectiveness and efficiency of the sustainability of the production process, or, according to Ramirez and Nembhard (2004), it can be called as knowledge-worker productivity.

Knowledge-worker productivity comes from organizational factors in the form of culture, organizational strategy, technology, reward systems, and work environment (Bosch-Sijtsema et al., 2009), innovation potential, information systems, clear vision, time allocation (Antikainen and Lönnqvist, 2006), organizational structure, human resources, and organizational ability to utilize workers' knowledge to produce an innovative product to support performance improvement (Kianto et al., 2018). PT. Pindad (Persero), as a knowledge-based company, took a strategic step by implementing a Knowledge Management System in 2018. This strategy was carried out in order to encourage employee activities to create, store, distribute, and utilize knowledge as a resource to improve and solve knowledgeworker productivity problems. Implementation of knowledge management system is 
reflected in the Employee Competency Development Program with a realization of $133.07 \%$. In addition, the levels of job satisfaction and employee engagement increased by 0.04 and 0.01 points, respectively, since the implementation of knowledge management in 2018 (PT. Pindad (Persero), 2019).

Knowledge management is thus closely related to knowledge-worker productivity. Butt et al. (2018) prove in their research that the knowledge management process can increase knowledge-worker productivity. Tsirikas and Katsaros (2014), Ritsri and Meeprom (2019) and Ibidunni et al. (2019) also proves that employee productivity is positively influenced by knowledge management practices. In addition, and more specifically, the knowledge sharing process, also has a significant positive effect on increasing employee productivity (Salis and Williams, 2010; Aboelmaged, 2018; Torabi and El-Den, 2017). However, this is different from the research of Kianto et al. (2018) which reveals that the productivity of knowledge workers is not significantly affected by the knowledge sharing process. Several knowledge management processes such as knowledge creation, knowledge retention, and knowledge sharing are also proven to have no significant positive impact on employee productivity (Lapré and Wassenhove, 2001; Okonedo and Popoola, 2012; Ajibade, 2016; Palvalin et al, 2018), while Capello and Lenzi (2014) prove that the knowledge creation process negatively affects employee productivity. The inconsistency of the research results allows the existence of mediating variables that have an important role in directing the knowledge-worker productivity because of the practice of knowledge management.

Research conducted by Almahamid et al. (2010), Malik and Kanwal (2018), and Zamir (2019) shows that knowledge management affects adaptability, while adaptability affects the knowledge-worker productivity (Diamantidis and Chatzoglou,
2019; Sony and Mekoth, 2016). In addition, research conducted by Almahamid et al. (2010), Kianto et al. (2016), Malik and Kanwal (2018), Sahibzada et al. (2020), Singh and Sharma (2011), Trivellas et al. (2015), and Tsirikas and Katsaros (2014) shows that knowledge management affects job satisfaction, while job satisfaction affects the knowledgeworker productivity (Halkos and Bousinakis, 2010; Hoboubi et al., 2017; Maida et al., 2017). By considering several previous studies, this study will examine the determination of knowledge-worker productivity with the role of knowledge management through adaptability and job satisfaction as mediating variables.

\section{LITERATURE REVIEW Knowledge-worker Productivity}

Drucker (1999) defines knowledgeworker productivity as the condition where there is an increase in the quality of output by knowledge-workers who are able to manage their work independently by being responsible for following a continuous learning process until sustainable innovation is achieved. According to Antikainen and Lönnqvist (2006), knowledge worker productivity describes conditions for improving the quality of an output, efficiency, and control of working time that involves the ability to change employee knowledge as required by the organization. Furthermore, Butt et al. (2018) describe knowledge-worker productivity as a form of worker efficiency in using their knowledge to make effective decisions and improvise knowledge-based tasks.

Conditions that can reflect knowledge-worker productivity include: Job autonomy, is a condition where employees can carry out work independently (Drucker, 1999; Morgeson and Humphrey, 2006); Timeliness, indicating a situation where employees are able to manage time according to work deadlines (Ramirez and Nembard, 2004; Lerner et al., 2001); Task efficiency, describes the 
ability of workers to perform tasks using resources properly to meet all job standards (Ramirez and Nembhard, 2004), with reference to the minimum level of resources theoretically required to carry out the desired operation (Tangen, 2005).

\section{Knowledge Management}

Knowledge management is an optimization strategy of a business system to select, filter, store, organize, package, and communicate important information for the company's business for the purpose of improving employee performance and company competitiveness (Bergeron, 2003). Pandey (2016) states that knowledge management is a broad field of science consisting of the process of creating, collecting, sharing, utilizing, and capitalizing on knowledge in organizations. In accordance with the opinion of Armstrong and Taylor (2014), knowledge management includes activities to create knowledge, acquire and capture knowledge, share knowledge, and use knowledge to enhance learning and employee performance.

Knowledge management processes include: Knowledge discovery, is the process of finding knowledge from data and information to be developed into new tacit or explicit knowledge (BecerraFernandez and Sabherwal, 2015); Knowledge capture, is the process of acquiring knowledge that exists in people or organizations, both explicit and tacit knowledge, which is facilitated by technology and organizational mechanisms (Becerra-Fernandez and Sabherwal, 2015); Knowledge sharing, is the process of sharing tacit and explicit knowledge with others (Becerra-Fernandez and Sabherwal, 2015); Knowledge application, is the process of individuals taking advantage of the knowledge of others without actually gaining the actual experience (BecerraFernandez and Sabherwal, 2015).

\section{Adaptability}

Individual adaptability is the ability, skill, motivation and willingness of individuals, to change themselves to different environmental (Ployhart and Bliese, 2006). Ployhart and Bliese (2006) describe individual adaptability as a combination of knowledge, attitudes, cognitive understanding, personality, values and interests, physical abilities and other characteristics. The combination predicts adaptive performance such as contextual tasks, counterproductive behavior, and so on, which allows for changes in various ways and dimensions of task, social, and environmental. Dam (2015) says that adaptability in the work context has a similar meaning to adaptive performance behavior (that is, behavior that if it leads to successful performance, it will be considered adaptive).

Adaptability, which is closely related to knowledge, comes from cognitive resources (Dam, 2015) including: Learn, is individual's ability to prepare for, and learn what is needed for future assignments (Pulakos et al, 2006); Creative, is the individual's readiness to solve atypical, unclear, and complex problems (Pulakos et al, 2006).

\section{Job Satisfaction}

Job satisfaction is a pleasant attitude of workers at work (Armstrong and Taylor, 2014). Job satisfaction is the view of workers about how much work can supply their desires (Luthans, 2011). Employees with high job satisfaction usually have good feelings, while employees with low job satisfaction usually have bad feelings about their work (Robbins and Judge, 2017). Colquitt et al (2015) present the same thing that job satisfaction is described as a pleasant emotion towards his job, whether favorable or unfavorable for him.

Job satisfaction indicators are as follows: Nature of work, refers to employees' feelings of pleasure towards the characteristics of the work itself, whether the task is useful, interesting, meaningful, and comfortable (Spector, 1997); Communication, refers to employ- 
yees' feelings of pleasure towards the flow of information in the organization needed to support their work (Spector, 1997); Operating conditions, refer to employees' feelings of pleasure towards existing work rules and procedures to support job completion (Spector, 1997); Contingent rewards, refer to employees' feelings of pleasure for the appreciation given by the organization such as awards or recognition for their work (Spector, 1997).

\section{Hypothesis Development}

Effect of Knowledge Management on Knowledge-worker Productivity

Managing knowledge effectively enables organizations to become more productive and efficient, generate solutions and develop more innovative organizational processes (BecerraFernandez and Sabherwal, 2015). Organizational practices that provide opportunities for workers to exchange knowledge can increase knowledge-worker productivity (Antikainen and Lönnqvist, 2006).

Organizations that have learning strategies and practices and share knowledge between teams will have a good impact on the quality of work results (Bosch-Sijtsema et al, 2009). Butt et al (2018) prove that prove that the increase of knowledge-worker productivity is influenced by the knowledge management process. Thus, the research hypothesis is presented as follows:

H1 : Knowledge management has a significant positive effect on knowledge-worker productivity.

\section{Effect of Knowledge Management on Adaptability}

Knowledge management can encourage employees to continue to learn from each other, so that employees have the knowledge needed to adapt whenever there are demands from the organization (Becerra-Fernandez and Sabherwal, 2015). Employees with a lot of knowledge will easily be aware of potential changes that are happening, so they are better prepared to face future challenges and respond quickly to organizational changes (Becerra-Fernandez and Sabherwal, 2015).

The knowledge possessed by workers can facilitate them in increasing their adaptability (Ployhart and Bliese, 2006; Pulakos et al, 2006). Almahamid et al (2010), Malik and Kanwal (2018), and Zamir (2019) prove that knowledge management has a great impact on increasing adaptability. Thus, the research hypothesis is presented as follows:

$\mathrm{H} 2$ : Knowledge management has a significant positive effect on adaptability.

\section{Effect of Adaptability on Knowledge- worker Productivity}

Employees with good adaptability usually have new ideas and are able to be actively involved in the discussion process so that they can come up with solutions to increase work effectiveness and efficiency (Becerra-Fernandez and Sabherwal, 2015). Individuals with a high level of adaptation are more resistant to work pressure and will show better work quality and work performance (Parent, 2010).

Diamantidis and Chatzoglou (2019), as well as Sony and Mekoth (2016) prove that adaptability has a positive effect on increasing employee performance. Thus, the research hypothesis is presented as follows:

H3 : Adaptability has a significant positive effect on knowledge-worker productivity.

\section{Effect of Knowledge Management on Job Satisfaction}

Knowledge management is able to boost employees to increase their knowledge so that they can successfully complete their tasks. This success has an effect on increasing employee motivation and self-confidence, so employees feel more satisfied at work (Becerra-Fernandez and Sabherwal, 2015). 
Several approaches to knowledge management, such as mentoring and training, are useful in motivating employees so as to increase job satisfaction (Becerra-Fernandez and Sabherwal, 2015). Kianto et al (2016), Sahibzada et al (2020), Singh and Sharma (2011), Tsirikas and Katsaros (2014) shows that the knowledge management process is significantly related to high job satisfaction. Thus, the research hypothesis is presented as follows:

H4 : Knowledge management has a significant positive effect on job satisfaction.

\section{Effect of Job Satisfaction on Knowledge- Worker Productivity}

Satisfied employees will be happy to seek and collect various information and knowledge that supports their work, and as a consequence are able to modify work methods, improvise work results or work time efficiency (Becerra-Fernandez and Sabherwal, 2015). Workers who feel happy and interested in their work will struggle to produce quality assignments (Antikainen and Lönnqvist, 2006).

Organizations with satisfied employees are usually more effective, and individuals with higher job satisfaction have better performance (Robbins and Judge, 2017). Satisfied employees will work more effectively and show more positive performance ratings (Dipboye, 2018). Halkos and Bousinakis (2010), Hoboubi et al (2017), and Maida et al (2017) prove that job satisfaction has a positive effect on employee productivity. Thus, the research hypothesis is presented as follows:

H5 : Job satisfaction has a significant positive effect on knowledge-worker productivity.

\section{Effect of Knowledge Management on Knowledge-worker mediated by Adaptability}

Knowledge management has succeeded in encouraging employees to continue learning with colleagues, so that employees have the information and knowledge they need to adapt. Employees with good adaptability then have a high level of new ideas and able to be actively involved in the discussion process, thus bringing up solutions to increase work effectiveness and efficiency in dealing with the complexities of changing organizational situations (Becerra-Fernandez and Shaberwal, 2015).

Diamantidis and Chatzoglou (2019) show that adaptability mediates the effect of management support on employee performance. Zamir (2019) proves that employee adaptation mediates knowledge management practices on employees' intentions to keep working. Thus, the research hypothesis is presented as follows:

H6 : Adaptability mediates the effect of knowledge management on knowledge-worker productivity.

\section{Effect of Knowledge Management on Knowledge-worker Productivity mediated by Job Satisfaction}

Knowledge management practices able to increase employee knowledge and the success of completing work, which in turn has an effect on increasing employee motivation and self-confidence so that employees feel more satisfied at work. Satisfied employees will then be happy to seek and collect various information and knowledge that supports their work, and then be able to modify the way of working, improvise work results or work time efficiency (Becerra-Fernandez and Sabherwal, 2015).

Sahibzada et al (2020) showed that job satisfaction was able to mediate knowledge management processes on improving organizational performance. Thus, the research hypothesis is presented as follows:

H7 : Job satisfaction mediates the effect of knowledge management on knowledge-worker productivity. 


\section{Conceptual Framework of the Research}

This research investigates four main constructs consisting of one independent variable (knowledge management), one dependent variable (knowledge-worker productivity), and two mediating variables (adaptability and job satisfaction). The research's conceptual framework is presented in Figure 1.

\section{RESEARCH METHODS}

Explanatory research is used as a research method. Explanatory research is carried out by testing hypotheses for the purpose of obtaining an overview of the relationship between variables (Solimun et al, 2017). Therefore, this research refers to quantitative research.

\section{Participants and Data Collection}

The population was made up of 389 employees of PT. Pindad (Persero) Malang who work in departments that are closely related to the knowledge of ammunition products, such as the departments of research and development, engineering, production, and product quality. Sampling was carried out proportionally and randomly from members of the population using a proportionate random sampling technique. A five-point Likert scale questionnaire was used for data collection, distributed as many as 270 copies, and 203 questionnaires could be processed finally. Questionnaires were distributed in the period August 2021 to September 2021.

\section{Instrument}

Knowledge-worker productivity is measured by three indicators: job autonomy, timeliness, and task efficiency using 12 statement items adapted from Morgeson and Humphrey (2006), Lerner et al. (2001), and Tangen (2005). Knowledge management is measured by four indicators: knowledge discovery, knowledge capture, knowledge sharing, and knowledge application using 12 statement items adapted from Tan and Wong (2015) and Tseng and Fan (2011). Adaptability was measured by two indicators: learn and creative, using 10 statement items adapted from Ployhart and Bliese (2006). Job satisfaction is measured by four indicators: nature of work, communication, operating conditions, and contingent rewards using 16 statement items adapted from Spector (1985).

\section{Data Analysis Technique}

Structural equation modeling (SEM) with partial least squares (PLS) approach was applied as a data analysis method using the WarpPLS7 application.

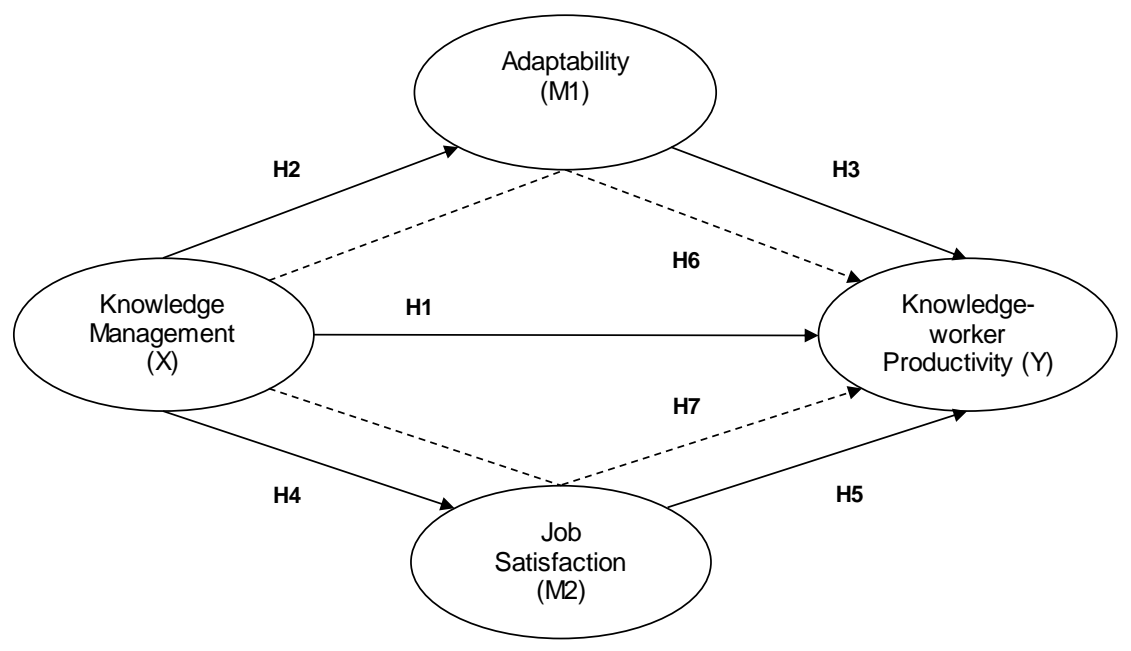

Figure 1. Conceptual Framework of the Research 


\section{RESULT AND DISCUSSION \\ Respondents' Characteristics}

The characteristics of respondents related to personal data of employees, including characteristics of work unit, gender, age, education level, and years of service, with the distribution of data presented in Table 1.

\section{Outer Model}

The outer model is intended to evaluate the relationship between latent variables and their indicators through testing the validity and reliability of research instruments (Kock, 2011; Solimun et al, 2017). The results of the outer model are presented in Table 2.

A research instrument obtains composite reliability if the composite reliability coefficient is greater than 0.70 ; obtains internal consistency reliability if Cronbach's alpha coefficient has a value greater than 0.60 (Kock, 2011); and obtains convergent validity if the AVE value is greater than 0.50 (Hair et al., 2014).

In Table 2, it can be seen that the composite reliability of all variables has a coefficient value above 0.70 ; Cronbach's alpha of all variables has a coefficient value above 0.60; and AVE for all variables has a value above 0.50 . Based on this, it can be concluded that the research instrument was declared reliable and valid.

\section{Inner Model (Goodness of fit)}

The Goodness of Fit is a test of measuring the goodness of latent variables related to the assumptions (Kock, 2011; Solimun et al, 2017). The value of Goodness of Fit is shown in Table 3.

A research instrument can be said to meet the criteria of Goodness of Fit if the p-value for the Average path coefficient (APC) and Average R-squared (ARS) is less than 0.05 or significant. In addition, the value of the Average block VIF (AVIF) as an indicator of multicollinearity must be less than 5. Sympson's paradox ratio (SPR) is a problem that occurs when the path coefficients of two variables and the correlations associated with the two variables have different signs. The acceptable SPR value is 0.70 (Kock, 2011; Sholihin and Ratmono, 2020).

In Table 3, it can be seen that the research instrument has an APC and an ARS p-value of less than 0.001, which means it is very significant, and the AVIF criteria meet the ideal requirements with a value of 1.049. The SPR value is 1 , which means the model is free from Sympson's paradox problems. Based on the results of these tests, it can be concluded that the research instrument meets the criteria of Goodness of Fit.

\section{Hypothesis Test}

Hypothesis testing is carried out with the following assumptions (Solimun dkk, 2017): it is said to be weakly significant if the p-value is 0.10 (an alpha of $10 \%$ ); it is said to be significant if the p-value is 0.05 (an alpha of 5\%); and it is said to be highly significant if the $\mathrm{p}$-value is 0.01 (an alpha of $1 \%$ ). P-values provide the power of the test and reflect the strength of the relationship (Kock, 2011).

\section{Hypothesis Test for Direct Effect}

The direct effect test was carried out to see the path coefficient and the significance level of the influence of one variable on the other variables according to the hypothesis of this study. The results of the direct effect test are shown in Figure 2.

The results of the first hypothesis test are the relationship between knowledge management $(\mathrm{X})$ and knowledge-worker productivity $(\mathrm{Y})$ which shows a positive path coefficient value of 0.077 ( $\mathrm{p}$-value of 0.132). Considering that the $p$-value is above 0.10 , it can be concluded that the knowledge management variable has no significant effect on the knowledge-worker productivity variable. Thus, statistically, the $\mathrm{H} 1$ proposed in this study was rejected.

The results of the second hypothesis test are the relationship between knowledge management (X) and 
adaptability (M1), which shows a positive path coefficient value of 0.287 (p-value less than 0.01). Considering that the $\mathrm{p}$ value is less than 0.01 , it can be concluded that the variable knowledge management has a significant positive effect on the adaptability variable. Thus, statistically, the $\mathrm{H} 2$ proposed in this study is accepted.

The result of the third hypothesis test is the relationship between adaptability (M1) and knowledge-worker productivity (Y), which shows a positive path coefficient value of 0.259 ( $\mathrm{p}$-value less than 0.01). Considering that the $p$-value is less than 0.01 , it can be concluded that the adaptability variable has a significant positive effect on the knowledge-worker productivity variable. Thus, statistically, $\mathrm{H} 3$ proposed in this study is accepted.

The results of the fourth hypothesis test are the relationship between knowledge management $(\mathrm{X})$ and the job satisfaction (M2), which shows a positive path coefficient value of 0.277 ( $p$-value less than 0.01). Considering that the $\mathrm{p}$ value is less than 0.01 , it can be concluded that the variable knowledge management has a significant positive effect on job satisfaction variables. Thus, statistically, $\mathrm{H} 4$ proposed in this study is accepted.

The result of the fifth hypothesis test is the relationship between job satisfaction (M2) and knowledge-worker productivity (Y), which shows a positive path coefficient value of 0.578 ( $p$-value less than 0.01 ). Considering that the $\mathrm{p}$-value is less than 0.01 , it can be concluded that the job satisfaction variable has a significant positive effect on the knowledge-worker productivity variable. Thus, statistically, H5 proposed in this study is accepted.

\section{Hypothesis Test for Indirect Effect}

The indirect effect test was conducted to examine the role of the mediating variable as an intermediary in the relationship between the independent variable and the dependent variable. Testing for the mediating effect of the relationship between $\mathrm{X}$ and $\mathrm{Y}$ was carried out in two stages (Kock, 2014; Carrión et al., 2017, Sholihin and Ratmono, 2020), and is presented in Table 4.

The result of the sixth hypothesis test is the relationship between knowledge management (X) and knowledge-worker productivity (Y), which is mediated by adaptability (M1). The path coefficient value of the knowledge management variable with the knowledge-worker productivity variable when testing the direct effect $(0.271$ with $\mathrm{p}$-value $<0.001)$ decreased in value and became insignificant after testing the indirect effect (0.077 with p-value 0.132). Furthermore, the path coefficient value between the knowledge management variable and the adaptability variable is 0.287 with a pvalue of $<0.001$, and the path coefficient value between the adaptability variable and the knowledge-worker productivity variable is 0.259 with a p-value of $<0.001$. Based on the test results, it can be concluded that the adaptability variable significantly mediates the effect of the knowledge management variable on the knowledge-worker productivity variable with a full mediation effect. Thus, statistically, H6 proposed in this study was accepted.

The result of the seventh hypothesis test is the relationship between knowledge management $(\mathrm{X})$ and knowledge-worker productivity (Y), which is mediated by job satisfaction (M2). The path coefficient value of the knowledge management variable with the knowledge-worker productivity variable when testing the direct effect (0.271 with p-value 0.001) decreased in value and became insignificant after testing the indirect effect (0.077 with p-value 0.132). Furthermore, the path coefficient value between the knowledge management variable and the job satisfaction variable is 0.277 with a $p$ value of $<0.001$, and the path coefficient value between the job satisfaction variable and the knowledge-worker productivity variable is 0.578 with a p-value of $<0.001$. Based on the test results, it can be 
concluded that the job satisfaction variable significantly mediates the effect of the knowledge management variable on the knowledge-worker productivity variable, with a full mediation effect. Thus, statistically, $\mathrm{H} 7$ proposed in this study was accepted.

Table 1. Respondents' Characteristics

\begin{tabular}{lcc}
\hline Characteristics & Frequency & Percentage \\
\hline Gender & & \\
Male & 192 & $95 \%$ \\
Female & 11 & $5 \%$ \\
Total & 203 & $100 \%$ \\
\hline Age (year) & & \\
$<30$ & 49 & $24 \%$ \\
$30-39$ & 57 & $28 \%$ \\
$40-49$ & 32 & $16 \%$ \\
$\geq 50$ & 65 & $32 \%$ \\
Total & 203 & $100 \%$ \\
\hline Education level & & \\
High school & 177 & $87 \%$ \\
Diploma & 4 & $2 \%$ \\
Bachelor & 20 & $10 \%$ \\
Master & 2 & $1 \%$ \\
Total & 203 & $100 \%$ \\
\hline Years of service & & \\
$<10$ & 96 & $47 \%$ \\
$10-19$ & 12 & $6 \%$ \\
$20-29$ & 67 & $33 \%$ \\
$\geq 30$ & 28 & $14 \%$ \\
Total & 203 & $100 \%$ \\
\hline & &
\end{tabular}

Table 2. Outer Model

\begin{tabular}{lccc}
\hline \multicolumn{1}{c}{ Variable } & $\begin{array}{c}\text { Composite } \\
\text { reliability } \\
\text { coefficients }\end{array}$ & $\begin{array}{c}\text { Cronbach's } \\
\text { alpha } \\
\text { coefficients }\end{array}$ & $\begin{array}{c}\text { Average Variances } \\
\text { Extracted (AVE) }\end{array}$ \\
\hline Knowledge Management (X) & 0.930 & 0.917 & 0.725 \\
Adaptability (M1) & 0.900 & 0.876 & 0.690 \\
Job Satisfaction (M2) & 0.933 & 0.924 & 0.685 \\
Knowledge-worker Productivity (Y) & 0.940 & 0.930 & 0.753 \\
\hline
\end{tabular}

Table 3. Inner Model (Goodness of fit)

\begin{tabular}{lccc}
\hline \multicolumn{1}{c}{ Model fit and quality indices } & Fit Criteria & $\begin{array}{c}\text { Analysis } \\
\text { Results }\end{array}$ & Description \\
\hline Average path coefficient (APC) & $\mathrm{p}<0.05$ & 0.276 & Fit \\
Average R-squared (ARS) & $\mathrm{p}<0.05$ & 0.228 & Fit \\
Average block VIF (AVIF) & $\begin{array}{c}\text { Acceptable if } \leq 5, \\
\text { ideally } \leq 3.3\end{array}$ & 1.049 & Ideal \\
Sympson's paradox ratio (SPR) & $\begin{array}{c}\text { Acceptable if } \geq 0.7, \\
\text { ideally }=1\end{array}$ & 1.000 & Ideal \\
\hline
\end{tabular}




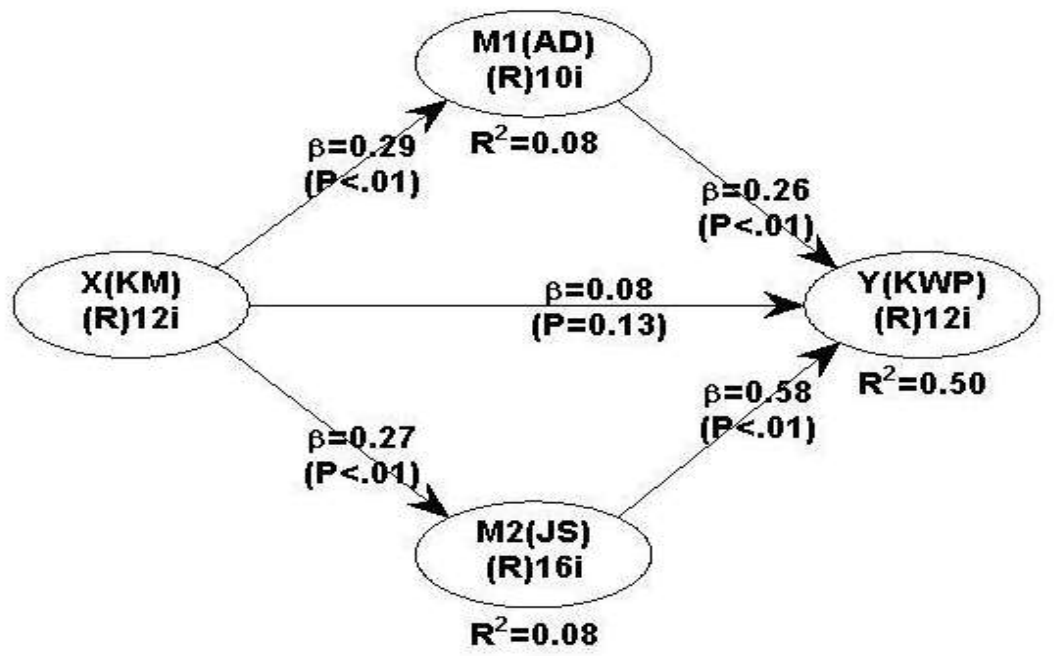

Figure 2. Path Model of Direct Effect Hypothesis

Table 4. Hypothesis Test for Indirect Effect

\begin{tabular}{|c|c|c|c|c|}
\hline $\begin{array}{c}\text { Relationship Between } \\
\text { Variables }\end{array}$ & $\begin{array}{c}\text { Path } \\
\text { Coefficient }\end{array}$ & $\mathrm{p}$-value & Analysis Results & Description \\
\hline \multicolumn{5}{|l|}{ Stage 1: Direct Effect } \\
\hline$X \rightarrow Y$ & 0.271 & $<0.001$ & Significant & $\begin{array}{l}\text { Fulfill the } \\
\text { mediation } \\
\text { requirements }\end{array}$ \\
\hline \multicolumn{5}{|l|}{ Stage 2: Indirect Effect } \\
\hline $\mathrm{X} \rightarrow \mathrm{Y}$ & 0.077 & 0.132 & Not significant & \multirow{3}{*}{$\begin{array}{l}\text { M1 as full } \\
\text { mediation }\end{array}$} \\
\hline $\mathrm{X} \rightarrow \mathrm{M} 1$ & 0.287 & $<0.001$ & Significant & \\
\hline $\mathrm{M} 1 \rightarrow \mathrm{Y}$ & 0.259 & $<0.001$ & Significant & \\
\hline $\mathrm{X} \rightarrow \mathrm{Y}$ & 0.077 & 0.132 & Not significant & \multirow{3}{*}{$\begin{array}{l}\text { M2 as full } \\
\text { mediation }\end{array}$} \\
\hline $\mathrm{X} \rightarrow \mathrm{M} 2$ & 0.277 & $<0.001$ & Significant & \\
\hline $\mathrm{M} 2 \rightarrow \mathrm{Y}$ & 0.578 & $<0.001$ & Significant & \\
\hline
\end{tabular}

\section{Discussion}

\section{Effect of Knowledge Management on Knowledge-worker Productivity}

The results of the first hypothesis test of this study indicate that knowledge management $(\mathrm{X})$ has no significant effect on knowledge-worker productivity (Y).

The insignificant effect is possible because PT. Pindad (Persero) has a tight production schedule that fulfills all working hours, so that employees do not have more time to explore company data, hold brainstorming activities with colleagues, or form a new team. In addition, knowledge management practice is still limited in its implementation during the COVID-19 pandemic, so it is not possible to see its direct effect on increasing knowledge-worker productivity. The insignificant effect is also predicted to occur because the level of maturity of knowledge management practices has never been measured by the company.

Knowledge-worker productivity is not significantly affected by knowledge management because of outside influences such as work stress due to heavy workloads (Halkos and Bousinakis, 2010), shift work schedules (Hoboubi et al., 2017), leadership style (Maida et al., 2017), and employee personal traits and attitudes (Tsirikas and Katsaros, 2014).

The results of this study are similar to those conducted by Lapre and Wassenhove (2001), Okonedo and Popoola (2012), Ajibade (2016), Kianto et al 
(2018), Palvalin et al (2018), and Capello and Lenzi (2014) which essentially show that knowledge management practices have no significant positive impact on increasing employee productivity.

\section{Effect of Knowledge Management on Adaptability}

The results of the second hypothesis test of this study indicate that knowledge management $(\mathrm{X})$ has a significant positive effect on adaptability (M1).

The significant effect is possible because employees are accustomed to doing knowledge sharing activities with colleagues. Awareness of the importance of knowledge sharing activities in daily work is also based on the fact that PT. Pindad (Persero) Malang is a manufacturing company that produces ammunition and explosives with a high level of hazard risk, so employees realize their responsibility if the knowledge they have mastered is not shared with colleagues, as it will result in fatal production failures for themselves, coworkers, and even customers who use ammunition and explosives.

The results confirm the statement by Becerra-Fernandez and Sabherwal (2015) that knowledge management has an impact on the adaptability of employees because its practice is able to encourage employees to continue to learn from each other so that employees have the information and knowledge needed to adapt whenever there are demands from the organization. Employees who are active in discussing and sharing information are quicker to respond and accept organizational changes so that they are better prepared to face future challenges. The results also support the statement presented by Jundt et al. (2014) and Stagl et al. (2006), which states that the learning process and appropriate learning strategies contribute to adaptability because individuals use knowledge pools when looking at the environment for change, defining the change, and adapting to what it should be.
The results are in line with research conducted by Zamir (2019) which proves that knowledge management practices have a significant positive effect on increasing employee adaptability. The results are also in line with research conducted by Almahamid et al (2010) and Malik and Kanwal (2018) which found that the practice of sharing knowledge was able to foster employee adaptability.

\section{Effect of Adaptability on Knowledge- worker Productivity}

The results of the third hypothesis test of this study indicate that adaptability (M1) has a significant effect on knowledge-worker productivity (Y).

The significant effect of adaptability on knowledge-worker productivity is possible because employees have become accustomed to learning new things since they first worked at the company. The reason is that PT. Pindad (Persero) Malang has knowledge of ammunition and explosives, which are classified as specific types of knowledge that are very limited and expensive to transfer, so the process of building knowledge on defence products is carried out early on.

The results confirm the statement by Becerra-Fernandez and Sabherwal (2015) that organizations with employees who are able to predict the coming problems and are ready to adapt to changes in the future tend to be able to maintain the effectiveness and efficiency of the organization's work processes. Employees with good adaptability are able to be actively involved in the discussion process to come up with solutions to increase work effectiveness and efficiency to meet customer needs while dealing with the complexities of changing organizational situations. The results also support the theory presented by Parent (2010) that individuals who have high adaptability are more resistant to work pressure and will show better quality of work and performance. 
The results are similar to the research conducted by Diamantidis and Chatzoglou (2019), and Sony and Mekoth (2016) which succeeded in proving that employee adaptability has a positive impact on employee performance.

\section{Effect of Knowledge Management on Job Satisfaction}

The results of the fourth hypothesis test of this study indicate that knowledge management $(\mathrm{X})$ has a significant effect on job satisfaction (M2).

The significant effect is possible because of the knowledge management practices applied by PT. Pindad (Persero) is intended to improve employee competence so that employees have high motivation to study defence product science so that they are able to present a sense of pleasure and satisfaction at work.

The results are in accordance with the theory proposed by Becerra-Fernandez and Sabherwal (2015) that knowledge management is able to encourage employees to learn better, be more prepared to face change, and be able to solve work problems effectively, which has an effect on increasing employee motivation and self-confidence so that employees feel more satisfied at work. Several approaches to knowledge management, such as mentoring and training, are useful in motivating employees, which can further increase employee job satisfaction.

These results are in accordance with research conducted by Kianto et al. (2016), Sahibzada et al. (2020), Singh and Sharma (2011), and Tsirikas and Katsaros (2014), which have proven that an increase in job satisfaction can be influenced by the application of knowledge management. The results of the study are also in line with Almahamid et al. (2010), Malik and Kanwal (2018), and Trivellas et al. (2015) who found that employee job satisfaction was able to be influenced by the practice of sharing knowledge.

\section{Effect of Job Satisfaction on Knowledge- Worker Productivity}

The results of the fifth hypothesis test of this study indicate that job satisfaction (M2) has a significant effect on knowledge-worker productivity (Y).

The significant effect is possible because employees have a sense of love for the work they do. PT. Pindad (Persero) as a strategic industry running in the field of manufacturing state defence and security products makes employees have their own pride in doing their jobs. Employees feel that every task they do has great meaning and contributes to the nation, thereby creating a sense of satisfaction within themselves. Thus, this feeling of satisfaction encourages employees to work according to the targets set by the company, and in the end, they are able to achieve high knowledge-worker productivity.

The results are in accordance with the theory proposed by Becerra-Fernandez and Sabherwal (2015) that satisfied employees will be happy to seek and collect various types of information and knowledge that support their work, and, as a consequence, they are able to modify work methods, improvise work results, or maximize time efficiency. These results also support Dipboye (2018) who stated that satisfied employees will work more effectively and produce more positive performance ratings. Workers who feel happy and interested in their work will struggle to produce quality assignments (Antikainen and Lönnqvist, 2006).

The results are similar to the research conducted by Halkos and Bousinakis (2010), Hoboubi et al. (2017), and Maida et al. (2017) which succeeded in proving that job satisfaction has a significant effect to increase employee productivity.

\section{Effect of Knowledge Management on Knowledge-worker Productivity mediated by Adaptability}

The results of the sixth hypothesis test of this study indicate that adaptability 
(M1) significantly has a full mediation role between knowledge management $(\mathrm{X})$ and knowledge-worker productivity (Y). These results explain that the effect of knowledge management practices on increasing knowledge-worker productivity can only occur if employees have good adaptability.

The mediating effect of adaptability is possible because employees of PT. Pindad (Persero) Malang has a knowledgesharing culture that can increase awareness of the importance of adaptability in the workplace. Employees are aware of the demand to master defence product knowledge, especially in facing industry 4.0 where the company is undergoing a gradual transformation, including updating of ammunition and explosives production machines based on digital technology.

The results are in accordance with the theory proposed by Becerra-Fernandez and Sabherwal (2015) that when knowledge management applied by organizations successfully encourages employees to continue learning, employees tend to have the information and knowledge to adapt whenever needed. Employees with good adaptability then have a high level of awareness of new ideas and are able to be actively involved in the discussion process to bring up solutions to increase work effectiveness and efficiency in dealing with the complexities of changing organizational situations.

The results are similar to the research conducted by Diamantidis and Chatzoglou (2019) and Zamir (2019) which succeeded in proving that adaptability is able to mediate knowledge management practices on employee performance.

\section{Effect of Knowledge Management on Knowledge-worker Productivity mediated by Job Satisfaction}

The results of the seventh hypothesis test of this study indicate that job satisfaction (M2) significantly has a full mediation role between knowledge management $(\mathrm{X})$ and knowledge-worker productivity (Y). These results explain that the effect of knowledge management practices on increasing knowledge-worker productivity can only occur if employees have high job satisfaction.

The mediating effect of job satisfaction is possible because PT. Pindad (Persero) Malang has implemented knowledge management, one of which is in education and training programs. The program can improve employee competence, so that employees feel confident and happy in doing their jobs. With the growing love for this job, employees are then consciously involved in achieving performance by increasing knowledge-worker productivity.

These results are in accordance with the theory of Becerra-Fernandez and Sabherwal (2015) which says that knowledge management practices are able to encourage increased employee knowledge and successful completion of work, which has an effect on increasing employee motivation and self-confidence so that employees feel more satisfied at work. Satisfied employees will then be happy to seek and collect various pieces of information and knowledge that support their work, and as a consequence, be able to modify work methods, improvise work results, or work efficiently.

The results are similar to the research conducted by Sahibzada et al (2020) which succeeded in proving that job satisfaction is able to mediate knowledge management processes on improving organizational performance.

Job satisfaction is a variable that no doubt needs to be revealed in many human resource management studies considering its significant consequences for employee and organizational productivity (Gruneberg, 1979). Noermijati and Primasari (2015) found in their research that job satisfaction was able to mediate work motivation and job stress on employee performance. Noermijati et al. (2020) also prove in their research that 
employee job satisfaction is able to mediate compensation justice on employee performance with spiritual intelligence as a moderating variable. Job satisfaction also has a mediating role in the effect of leadership on employee performance (Rasmuji and Putranti, 2017).

\section{CONCLUSION AND RECOMMEN- DATION}

This study was conducted to examine the increase in knowledge-worker productivity which is influenced by knowledge management, with a focus on the mediating roles of adaptability and job satisfaction. The overall research results can be concluded as follows:

Knowledge management has no significant effect on knowledge-worker productivity. Therefore, it is possible to allow mediating variables that play a role in increasing knowledge worker productivity that is influenced by knowledge management.

Knowledge management has a significant positive effect on adaptability. It indicates that the better the knowledge management process, the greater the employees' adaptability. Meanwhile, adaptability has a significant positive effect on knowledge-worker productivity. It indicates that the better employees' adaptability, the higher the knowledgeworker productivity.

Knowledge management has a significant positive effect on job satisfaction. It indicates that the better the knowledge management process, the higher employees' job satisfaction. Meanwhile, job satisfaction has a significant positive effect on knowledgeworker productivity. It indicates that the higher employees' job satisfaction, the higher their knowledge-worker productivity.

This research concludes that adaptability and job satisfaction have a full mediating role. It indicates that the increase in knowledge-worker productivity influenced by knowledge management can only occur if employees have good adaptability and high job satisfaction.

This research contributes fill the research gap between knowledge management and knowledge-worker productivity with the presence of adaptability and job satisfaction as a mediating variable.

This study proves that knowledgeworker productivity can be influenced by organizational and individual factors. These results provide additional contributions to Resources Based Theory (RBT) which states that all available resources and company's capabilities is a foundation to improve competitive advantage (Grant, 1991).

The results showed that the knowledge management practice in defence industry requires top management commitment and initiation of establishing a system culture to encourage employees to create and explore knowledge, share knowledge with colleagues, and apply existing knowledge. Other than that, companies need to measure the maturity level of knowledge management implementation that has been applied to see the extent of effectiveness implementation. This is important to prevent the loss of company knowledge assets.

The results showed that the ability of employees to adapt dealing with organizational change is important in facilitating the increase in knowledge-worker productivity that is influenced by knowledge management of the defence industry. Companies need to encourage the habit of employees to learn new skills in doing work, quickly and proficiently perform tasks that have never been learned, and demonstrate actions to correct deficiencies in work performance. Employee failure in anticipating the changes in job demands can threaten business continuity.

The results showed that the employee's feeling of pleasure in doing work becomes important in facilitating the 
influence of management knowledge to increase knowledge-worker productivity in defence industry. Company needs to encourage the emergence of a sense of love for employees towards the task they do, by creating jobs with characteristics that challenging, interesting, to be proud of, increase personal responsibility and able to activate the main skills of employees. Decreased a sense of belonging towards work has the potential to be very dangerous especially in industrial companies with a high level of work risk.

This study uses the measurement of knowledge-worker productivity limited to job autonomy, timeliness, and task efficiency that are deemed appropriate with the condition of knowledge-worker productivity in the business unit under study. It becomes opportunities for future research to develop methods that rarely used in previous studies, such as customer satisfaction, importance of work, or work attendance. Business units in this study is limited to PT. Pindad (Persero) Malang. Future research may involve employees who work in other defence industry companies, or knowledge-based company engaged in the service industry.

\section{REFERENCES}

Aboelmaged, M. G. (2018). Knowledge sharing through enterprise social network (ESN) systems: motivational drivers and their impact on employees' productivity. Journal of Knowledge Management, 22(2), 362-383. doi:https://doi.org/10.1108/JKM05-2017-0188

Ajibade, P. (2016). The Role of Knowledge Management in Improving Small, Micro and Medium Enterprises Productivity: A Case of Nkonkobe Municipality, South Africa. Journal of Social Sciences, $\quad 47(3), \quad 229-238$. doi:https://doi.org/10.1080/097189 23.2016.11893563
Almahamid, S., McAdams, A. C., \& Kalaldeh, T. (2010). The Relationships among Organizational Knowledge Sharing Practices, Employees' Learning Commitments, Employees' Adaptability, and Employees' Job Satisfaction: An Empirical Investigation of the Listed Manufacturing Companies in Jordan. Interdisciplinary Journal of Information, Knowledge, and Management, 5, 327-356.

Antikainen, R., \& Lönnqvist, A. (2006). Knowledge Work Productivity Assessment. Tampere: ResearchGate. Retrieved from https://www.researchgate.net/publi cation/228397441_Knowledge_wor k_productivity_assessment

Armstrong, M., \& Taylor, S. (2014). Armstrong's Handbook of Human Resources Management Practice (13 ed.). London: Koganpage.

Becerra-Fernandez, I., \& Sabherwal, R. (2015). Knowledge Management Systems and Processes (2 ed.). New York: Routledge Taylor \& Francis Group.

Bergeron, B. (2003). Essentials of Knowledge Management. New Jersey: John Wiley \& Sons, Inc.

Bosch-Sijtsema, P. M., Ruohomaki, V., \& Vartiainen, M. (2009). Knowledge work productivity in distributed teams. Journal of Knowledge Management, 13(6), 533-546. doi:http://dx.doi.org/10.1108/13673 270910997178

Butt, M. A., Nawaz, F., Hussain, S., José Sousa, M., Wang, M., Sumbal, M. S., \& Shujahat, M. (2018). Individual knowledge management engagement, knowledge-worker productivity, and innovation performance in knowledge-based organizations: the implications for knowledge processes and knowledge-based systems. Computational and Mathematical 
Organization Theory, 25, 336-356. doi:https://doi.org/10.1007/s10588018-9270-z

Capello, R., \& Lenzi, C. (2014). Knowledge, Innovation and Productivity Gains across European Regions. Regional Studies, 1-17. doi:http://dx.doi.org/10.1080/00343 404.2014.917167

Carrión, G. C., Nitzl, C., \& Roldán, J. L. (2017). Mediation Analyses in Partial Least Squares Structural Equation Modeling: Guidelines and Empirical Examples. In H. Latan, \& R. Noonan, Partial Least Squares Path Modeling: Basic Concepts, Methodological Issues and Applications (pp. 173-195). Cham: Springer International Publishing. doi:10.1007/978-3-31964069-3

Colquitt, J. A., Lepine, J. A., \& Wesson, M. J. (2015). Organizational Behavior. Improving Performance and Commitment in the Workplace (4 ed.). New York: McGraw-Hill Education.

Dam, K. v. (2015). Employee adaptability to change at work: a multidimensional, resource-based framework. In A. D. Vos, \& B. I. Heijden, Handbook of Research on Sustainable Careers (pp. 123-142). Glos: Edward Elgar Publishing Limited.

doi:10.4337/9781782547037

Diamantidis, A. D., \& Chatzoglou, P. (2019). Factors affecting employee performance: an empirical approach. International Journal of Productivity and Performance Management, 68(1), 171-193. doi:https://doi.org/10.1108/IJPPM01-2018-0012

Dipboye, R. L. (2018). Work-Related Attitudes in Organizations. The Emerald Review of Industrial and Organizational Psychology, 175212. doi:https://doi.org/10.1108/978-178743-785-220181007

Drucker, P. F. (1999). Knowledge-Worker Productivity: The Biggest Challenge. California Management Review, 41(2), 79-85. doi:https://doi.org/10.2307\%2F411 65987

Grant, R. M. (1991). The Resource-Based Theory of Competitive Advantage: Implications for Strategy Formulation. California Management Review, 33(3), 114135.

Gruneberg, M. M. (1979). Understanding Job Satisfaction. London: The Macmillan Press Ltd.

Hair, J. F., Sarstedt, M., Hopkins, L., \& Kuppelwieser, V. G. (2014). Partial least squares structural equation modeling (PLS-SEM): An emerging tool in business research. European Business Review, 26(2), 106-121. doi:10.1108/EBR-102013-0128

Halkos, G., \& Bousinakis, D. (2010). The effect of stress and satisfaction on productivity. International Journal of Productivity and Performance Management, 59(5), 415-431. doi:https://doi.org/10.1108/174104 01011052869

Hoboubi, N., Choobineh, A., Ghanavati, F. K., Keshavarzi, S., \& Hosseini, A. A. (2017). The Impact of Job Stress and Job Satisfaction on Workforce Productivity in an Iranian Petrochemical Industry. Safety and Health at Work, 8, 67-71. doi:https://doi.org/10.1016/j.shaw.2 016.07 .002

Ibidunni, A. S., Abiodun, J. A., Ibidunni, O. M., \& Olokundun, M. A. (2019). Using explicit knowledge of groups to enhance firm productivity: A data envelopment analysis application. South African Journal of Economic and Management Sciences, 22(1), a2159. 
doi:https://doi.org/10.4102/sajems. v22i1.2159

Jundt, D. K., Shoss, M. K., \& Huang, J. L. (2014). Individual adaptive performance in organizations: A review. Journal of Organizational Behavior, 1-19. doi:https://doi.org/10.1002/job.195 5

Kianto, A., Shujahat, M., Hussain, S., Nawaz, F., \& Ali, M. (2018). The impact of knowledge management on knowledge worker productivity. Baltic Journal of Management, 121.

doi:https://doi.org/10.1108/BJM12-2017-0404

Kianto, A., Vanhala, M., \& Heilmann, P. (2016). The impact of knowledge management on job satisfaction. Journal of Knowledge Management, 20(4), 621-636. doi:https://doi.org/10.1108/JKM10-2015-0398

Kock, N. (2011). Using WarpPLS in eCollaboration Studies: Descriptive Statistics, Settings, and Key Analysis Results. International Journal of e-Collaboration, 7(2), 118. doi:10.4018/jec.2011040101

Kock, N. (2014). Advanced Mediating Effects Tests, Multi-Group Analyses, and Measurement Model Assessments in PLS-Based SEM. International Journal of $e$ Collaboration, 10(1), 1-13. doi:10.4018/ijec.2014010101

Lapré, M. A., \& Wassenhove, L. V. (2001). Creating and Transferring Knowledge for Productivity Improvement in Factories. Management Science, 47(10), 1311-1325. doi:http://dx.doi.org/10.1287/mnsc. 47.10.1311.10264

Lerner, D., Amick, B. C., Rogers, W. H., Malspeis, S., Bungay, K., \& Cynn, D. (2001). The Work Limitations Questionnaire. Medical Care, 39(1), 72-85.
Luthans, F. (2011). Organizational Behavior: An Evidence-Based Approach (12 ed.). New York: The McGraw-Hill Companies, Inc.

Maida, M. T., Riyanto, S., \& Ali, H. (2017). Effect of Job Satisfaction and Leadership Style towards Employee Productivity at PT Asuransi Umum Bumiputera Muda 1967. Saudi Journal of Business and Management Studies, 2(3A), 157-168. doi:10.21276/sjbms.2017.2.3.7

Malik, M. S., \& Kanwal, M. (2018). Impacts of organizational knowledge sharing practices on employees' job satisfaction: Mediating roles of learning commitment and interpersonal adaptability. Journal of Workplace Learning, $\quad 30(1), \quad 2-17$. doi:https://doi.org/10.1108/JWL05-2016-0044

Morgeson, F. P., \& Humphrey, S. E. (2006). The Work Design Questionnaire (WDQ): Developing and Validating a Comprehensive Measure for Assessing Job Design and the Nature of Work. Journal of Applied Psychology, 91(6), 1321$1339 . \quad$ doi:10.1037/00219010.91.6.1321

Noermijati, N., \& Primasari, D. (2015). The effect of job stress and job motivation on employees' performance through job satisfaction (A study at PT. Jasa Marga (Persero) Tbk. Surabaya Gempol branch). Journal of Economics, Business, and Accountancy Ventura, 18(1), 231240.

doi:http://dx.doi.org/10.14414/jeba v.v18i2.450

Noermijati, N., Adi, A. N., Firdaus, E. Z., \& Masterizki, H. G. (2020). Job Satisfaction as a Mediation Role and Spiritual Intelligence as a Moderation Effect to Compensational Justice to the 
Government Banking Employees Performance in Malang City. PalArch's Journal of Archaeology, 17(3), 236-257. doi:https://doi.org/10.48080/jae.v17 i3.81

Okonedo, S., \& Popoola, S. (2012). Effect of Self-concept, Knowledge Sharing and Utilization on Research Productivity Among Librarians in Public Universities in South-West, Nigeria. Library Philosophy and Practice (ejournal), 865.

Palvalin, M., Vuori, V., \& Helander, N. (2018). The relation between knowledge transfer and productivity in knowledge work. Knowledge Management Research \& Practice, 16(1), 118-125. doi:https://doi.org/10.1080/147782 38.2018.1428067

Pandey, K. N. (2016). Paradigms of Knowledge Management: With Systems Modelling Case Studies. Haryana: Springer India.

Parent, J. D. (2010). Individual Adaptation to the Changing Workplace: A Model of Causes, Consequences, and Outcomes. Contemporary Occupational Health Psychology. 1, pp. 188-207. West Sussex: John Wiley \& Sons Ltd.

Ployhart, R. E., \& Bliese, P. D. (2006). Individual Adaptability (I-ADAPT) Theory: Conceptualizing the Antecedents, Consequences, and Measurement of Individual Differences in Adaptability. Advances in Human Performance and Cognitive Engineering Research, 6, 3-39. doi:https://doi.org/10.1016/S14793601(05)06001-7

PT. Pindad (Persero). (2019, December 31). Annual Report 2019. Retrieved July 20, 2021, from PT. Pindad (Persero): https://pindad.com/annual-report
PT. Pindad (Persero). (2021, July 20). Product and Services: Ammunition. Retrieved July 20, 2021, from PT. Pindad (Persero): https://pindad.com/ammunition

Pulakos, E. D., Dorsey, D. W., \& White, S. S. (2006). Adaptability in the Workplace: Selecting an Adaptive Workforce. Advances in Human Performance and Cognitive Engineering Research, 6, 41-71. doi:http://dx.doi.org/10.1016/S1479 -3601(05)06002-9

Ramirez, Y. W., \& Nembhard, D. A. (2004). Measuring knowledge worker productivity: A taxonomy. Journal of Intellectual Capital, 5(4), 602-628. doi:https://doi.org/10.1108/146919 30410567040

Rasmuji, R., \& Putranti, R. D. (2017). Pengaruh Efektivitas Kepemimpinan dan Lingkungan Kerja Terhadap Kinerja Karyawan dengan Peran Mediasi Kepuasan Kerja (Studi pada PD. BPR BKK Batang). Media Ekonomi dan Manajemen, 32(2), 178-194. doi:http://dx.doi.org/10.24856/mem .v32i2.539

Ritsri, U., \& Meeprom, S. (2019). Does knowledge management practice produce accounting employee productivity in the tourism business in Thailand? An International Journal of Tourism and Hospitality Research, 1-12. doi:https://doi.org/10.1080/130329 17.2019.1708424

Robbins, S. P., \& Judge, T. A. (2017). Organizational Behavior (17 ed.). Essex: Pearson Education Limited.

Sahibzada, U. F., Cai, J., Latif, K. F., \& Sahibzada, H. F. (2020). Knowledge management processes, knowledge worker satisfaction, and organizational performance: Symmetric and asymmetrical analysis. Aslib Journal of Information Management, 72(1), 
112-129.

doi:https://doi.org/10.1108/AJIM-

10-2019-0276

Salis, S., \& Williams, A. M. (2010). Knowledge Sharing through Faceto-Face Communication and Labour Productivity: Evidence from British Workplaces. British Journal of Industrial Relations, 48(2), 436-459. doi:https://doi.org/10.1111/j.14678543.2009.00762.x

Sholihin, M., \& Ratmono, D. (2020). Analisis SEM-PLS dengan WarpPLS 7.0 untuk Hubungan Nonlinier dalam Penelitian Sosial dan Bisnis (2 ed.). Yogyakarta: CV Andi Offset.

Singh, A. K., \& Sharma, V. (2011). Knowledge management antecedents and its impact on employee satisfaction: A study on Indian telecommunication industries. The Learning Organization, 18(2), 115-130. doi:http://dx.doi.org/10.1108/09696 471111103722

Solimun, S., Fernandes, A. A., \& Nurjannah, N. (2017). Metode Statistika Multivariat. Pemodelan Persamaan Struktural (SEM). Pendekatan WarpPLS. Malang: UB Press.

Sony, M., \& Mekoth, N. (2016). The relationship between emotional intelligence, frontline employee adaptability, job satisfaction and job performance. Journal of Retailing and Consumer Services, 30, 20-32. doi:http://dx.doi.org/10.1016/j.jretc onser.2015.12.003

Spector, P. E. (1985). Measurement of Human Service Staff Satisfaction: Development of the Job Satisfaction Survey. American Journal of Community Psychology, 13(6), 693-713. doi:https://doi.org/10.1007/BF0092 9796
Spector, P. E. (1997). Job Satisfaction. Application, Assessment, Cause, and Consequences. California: SAGE Publications.

Stagl, K. C., Burke, C. S., Salas, E., \& Pierce, L. (2006). Team Adaptation: Realizing Team Sinergy. In C. S. Burke, L. G. Pierce, \& E. Salas, Understanding Adaptability: A Prerequisite for Effective Performance Within Complex Environments (pp. 117141). Oxford: Elsevier Ltd. doi:https://doi.org/10.1016/S14793601(05)06004-2

Tan, L. P., \& Wong, K. Y. (2015). Linkage between knowledge management and manufacturing performance: a structural equation modeling approach. Journal of Knowledge Management, 19(4), 814-835. doi:http://dx.doi.org/10.1108/JKM11-2014-0487

Tangen, S. (2005). Demystifying productivity and performance. International Journal of Productivity and Performance Management, 54(1), 34-46. doi:http://dx.doi.org/10.1108/17410 400510571437

Torabi, F., \& El-Den, J. (2017). The impact of Knowledge Management on Organizational Productivity: A Case Study on Koosar Bank of Iran. 4th Information Systems International Conference 2017, ISICO 2017. 124, pp. 300-310. Bali: Procedia Computer Science. doi:https://doi.org/10.1016/j.procs. 2017.12.159

Trivellas, P., Akrivouli, Z., Tsifora, E., \& Tsoutsa, P. (2015). The impact of knowledge sharing culture on job satisfaction in accounting firms. The mediating effect of general competencies. The Economies of Balkan and Eastern Europe Countries in the changed world, EBEEC 2014. 19, pp. 238-247. Nis: Procedia Economics and Finance. 
doi:https://doi.org/10.1016/S22125671(15)00025-8

Tseng, F.-C., \& Fan, Y.-J. (2011). Exploring the Influence of Organizational Ethical Climate on Knowledge Management. Journal of Business Ethics, 101, 325-342. doi:https://doi.org/10.1007/s10551010-0725-5

Tsirikas, A. N., \& Katsaros, K. K. (2014). Linking knowledge management, job satisfaction and productivity in the Greek public sector. International Journal Knowledge Management Studies, 5(3/4), 245264.

Zamir, Z. (2019). The Impact of Knowledge Capture and Knowledge Sharing on Learning, Adaptability, Job Satisfaction and Staying Intention: A Study of the Banking Industry in Bangladesh. International Journal of Entrepreneurial Knowledge, 7(1), 46-64. doi:10.2478/IJEK-20190004 